\title{
HUBUNGAN SPESIALISASI SEL DENGAN KANDUNGAN IAA PADA KULTUR SEL Catharanthus roseus DENGAN PENAMBAHAN TRIPTOFAN
}

\section{THE CORELATION CELL SPECIALIZATION WITH IAA CONTENT OF Catharanthus roseus CELL CULTURE BY THE ADDITION OF TRYPTOPHAN}

\author{
Dingse Pandiangan1), Wenny Tilaar2), dan Nelson Nainggolan ${ }^{3)}$ \\ 1)Jurusan Biologi FMIPA UNSRAT Manado JI. Kampus Unsrat Manado, 95115. Emaildingsepan@yahoo.com \\ 2)Jurusan Agronomi Pertanian UNSRAT Manado \\ 3)Jurusan Matematika FMIPA UNSRAT Manado
}

\begin{abstract}
The corelation cell specialization with IAA (indole acetic acid) content of Catharanthus roseus cell culture by the addition of tryptophan has been done. This research is part of a strategy to increased the catharanthine content. One strategy used is the addition of tryptophan as a precursor treatment. IAA was other compound of the effect of the addition of tryptophan. Research was conducted in the laboratory using MS medium with tryptophan $50-250 \mathrm{mg} / \mathrm{L}$. The cell morphology observations made by Halogen Nikon microscope and documented with a digital camera Nikon DXM 1200F. The results showed that cell morphology is essentially the same for each treatment. The differences seen is the presence of more the long cells in the treatment of tryptophan. The longest ratio is the treatment of 150 $\mathrm{mg} / \mathrm{L}$ tryptophan at day 14 of culture. Changes in cell morphology relationship more long (run specialization) has something to do with the IAA content after treatment tryptophan. The highest IAA content equal $214,79 \pm 0,90 \mu \mathrm{g} / \mathrm{g} \mathrm{dw}$ was occurred at day 14 th after being treated tryptophan $150 \mathrm{mg} / \mathrm{L}$ with $75 \%$ long cells or cells specialization. The relationship between the content of IAA specialized cells showed a positive correlation of 0.80 or $80 \%$ of each other.
\end{abstract}

Key words: Cell specialization, IAA content, catharanthine, tryptophan, Catharanthus roseus

\begin{abstract}
ABSTRAK
Hubungan antara spesialisasi sel dengan kandungan IAA (asam indol asetat) kultur sel Catharanthus roseus dengan perlakuan triptofan telah dilakukan. Penelitian ini merupakan bagian dari strategi peningkatan kandungan katarantin. Salah satu strategi yang digunakan adalah penambahan perlakuan triptofan sebagai prekursor. IAA merupakan hasil sampingan sebagai pengaruh penambahan triptofan. Penelitian ini dilakukan di laboratorium dengan menggunakan media MS dengan triptofan 50-250 mg/L. Pengamatan spesialisasi sel dilakukan dengan mikroskop Nikon Halogen dan didokumentasikan dengan kamera digital Nikon DXM 1200F. Bentuk sel pada dasarnya sama untuk setiap perlakuan. Perbedaan yang terlihat nyata adalah adanya sel-sel panjang lebih banyak pada perlakukan triptofan. Perlakuan yang paling panjang rationya adalah pada perlakuan $150 \mathrm{mg} / \mathrm{L}$ triptofan pada hari ke-14 kultur. Hubungan perubahan bentuk sel yang lebih banyak panjang (mengalami spesialisasi) ada hubungannya dengan kandungan IAA dan katarantin yang meningkat selelah perlakuan triptofan. Kandungan IAA paling tinggi yaitu sebesar $214,79 \pm 0,90 \mu \mathrm{g} / \mathrm{g}$ bk terjadi pada hari ke 14 selelah diberi perlakuan triptofan $150 \mathrm{mg} / \mathrm{L}$ dengan persentasi sel panjang atau sel mengalami spesialisasi $75 \%$. Hubungan antara spesialisasi sel dengan kandungan IAA menunjukkan hubungan yang positif sebesar 0,80 atau $80 \%$ saling menunjang.
\end{abstract}

Kata kunci: Spesialisasi sel, IAA, katarantin, triptofan, Catharanthus roseus 


\section{PENDAHULUAN}

Catharanthus roseus (L) G. Don), adalah semak tahunan yang banyak dibudidayakan sebagai tanaman hias dan obat. Tanaman ini sering disebut tapak dara. Tanaman tapak dara ini berguna untuk mengobati hipertensi, diabetes, pendarahan akibat penurunan jumlah trombosit, chorionic epthelioma, leukemia limfositik akut, leukemia monositik akut, limfosarkoma dan sarkoma sel reticulum (Alexandrova et al., 2000). Sekitar 100 macam alkaloid telah diidentifikasi pada tanaman ini (De Padua et al., 1999; Dutta et al., 2005), diantaranya adalah alkaloid antikanker seperti vinblastin, vinkristin, katarantin, leurosidin dan leurosin. Sutarno dan Rudjiman (2003) mengemukakan bahwa penghasil vindolin, vinkristin dan vinblastin yang dikomersialkan kebanyakan berasal dari tapak dara, terutama yang berbunga putih.

Produksi alkaloid dan katarantin dari $C$. roseus sudah dilakukan secara in vitro. Namun kandungan alkaloid dan katarantin mengalami fluktuasi sesuai jenis bioaktif yang diproduksi. Oleh karena itu strategi peningkatan kandungan alkaloid dan katarantin sudah dicobakan dengan berbagai metoda seperti penambahan prekursor, elisitasi dan amobilisasi (Pandiangan et al., 2008). Dari ketiga strategi tersebut penambahan prekursor merupakan peningkatan yang dapat berkelanjutan, oleh karena selnya tumbuh baik tetapi kandungan katarantinnya dapat meningkat dari kontrolnya.

Pandiangan et al. (2006a) melaporkan bahwa pendekatan penambahan prekursor sudah dilakukan. Perlakuan tirptofan pada kalus $C$. roseus dapat meningkatkan kandungan katarantin sampai 950,536 $\mu \mathrm{g} / \mathrm{g}$ berat kering (BK). Menurut Pandiangan (2010), bahwa kandungan IAA mengalami peningkatan juga dengan penambahan prekursor triptofan. Bagaimana hubungannya dengan pemanjangan sel $C$. roseus perlu pembuktian. Umumnya pada pertumbuhan kalus rendah menghasilkan kandungan katarantin yang lebih tinggi daripada pertumbuhan yang tinggi. Dari penelitian tersebut ditemukan pertumbuhan optimum adalah pada perlakuan $175 \mathrm{mg} / \mathrm{L}$ prekursor triptofan. Moreno-Valenzuela (1998), juga melaporkan bahwa pada sel yang mengalami spesialisasi dan diferensiasi menghasilkan metabolit sekunder yang tinggi pada kultur in vivo. Sel yang mengalami diferensiasi menunjukkan pertumbuhan yang lebih lambat dari pada yang undiferensiasi. Disamping itu, Girod dan Zryd (1991) melaporkan bahwa bentuk sel pada kultur kalus bit merah mempengaruhi akumulasi pigmen betalain. Bentuk sel yang silinder mengandung alkaloid lebih tinggi daripada bentuk bulat (sperikal), semakin panjang sel maka kandungan alkaloid semakin tinggi (Kim et al., 1994). Penambahan prekursor triptofan dapat meningkatkan kandungan katarantin (Pandiangan et al., 2006a) mungkin juga dapat menambah jumlah sel yang berbentuk silinder atau memanjang. Penelitian ini bertujuan untuk membuktikan bahwa pemanjangan sel atau spesialisasi sel $C$. roseus ada hubungannya dengan peningkatan kandungan IAA dan katarantin.

Berdasarkan pada latar belakang di atas maka permasalahan dalam penelitian ini adalah: Bagaimana respons pertumbuhan sel $C$. roseus yang diberi perlakuan triptofan? Bagaimana perubahan bentuk sel $C$. roseus dalam kaitannya dengan spesialisasi sel yang diberi perlakuan triptofan serta hubungannya dengan kandungan IAA?

\section{METODE PENELITIAN}

Penelitian ini dilaksanakan di 3 (tiga) laboratorium yaitu Laboratorium Biotek Pertanian Unsrat, Laboratorium SITH ITB Bandung dan Laboratorium Kimia Farmasi ITB Bandung. Waktu pelaksanaan sejak bulan Februari sampai dengan Juli 2012.

Tanaman yang digunakan sebagai sumber eksplan di dalam penelitian ini adalah Catharanthus roseus (L.) G. Don yang berbunga putih. Bahanbahan kimia yang digunakan adalah medium MS, disinfektan, etanol, NAA, kinetin, IAA, metanol, diklorometana, $\mathrm{HCl}, \mathrm{NaOH}$, asetonitril, diamonium hidrogen fosfat, $\mathrm{Na}_{2} \mathrm{SO}_{4}$ anhidrat, triptofan.

Alat-alat yang digunakan seperti peralatan gelas, laminar air flow cabinet, Alat-alat wadah dan gelas ukur, freeze dryer, shaker, timbangan digital, mikroskop Nikon Halogen 100W pada perbesaran 
10x10, kamera digital Nikon DXM 1200F, refrigerator, Camera digital Cannon, sentrifuge.

Penelitian menggunakan RAL (Rancangan Acak Lengkap) dengan 6 perlakuan penambahan triptofan yaitu control (T0) dan triptofan 50 (T1), 100 (T2), 150 (T3), 200 (T4), 250 (T5) mg/L (Pandiangan et al., 2006a) dan dilakukan dalam wadah Erlenmeyer $100 \mathrm{ml}$ Setiap satuan percobaan terdiri atas 3 ulangan dimana setiap ulangan terdiri dari 3 botol kultur.

\section{Prosedur Kerja: \\ Kultur dan Subkultur Kalus Untuk Memperoleh Stok Kalus}

Teknik kultur dan subkultur kalus dilakukan dengan teknik aseptik. Subkultur kalus ke medium baru dengan komposisi yang sama dengan medium produksi kalus. Kalus dipindahkan ke dalam medium MS padat yang ditambahkan zpt 2 $\mathrm{mg} / \mathrm{L}$ NAA dan 0,2 mg/L kinetin. Subkultur ini dilakukan secara terus-menerus untuk memperbanyak kalus sebagai sumber eksplan pada kultur sel dalam Erlenmeyer dan bioreaktor. Subkultur kalus dilakukan setiap 21 hari. Kalus yang digunakan sudah disubkultur selama 1 tahun 2 bulan.

\section{Kultur Agregat dan Sel}

Kultur sel digunakan labu Erlenmeyer 250 $\mathrm{mL}$. Setiap Erlenmeyer berisi $50 \mathrm{~mL}$ medium cair MS dengan kombinasi zpt yang sama dengan medium produksi kalus. Kalus yang digunakan sudah berusia sekitar 1 tahun lebih disubkultur. Kalus sebanyak $5 \mathrm{~g}$ dipindahkan ke medium MS cair $50 \mathrm{~mL}$ (Son et al., 2000), yang ditambahkan 2 $\mathrm{mg} / \mathrm{L}$ NAA dan $0,2 \mathrm{mg} / \mathrm{L}$ kinetin (medium NK atau T0) (Pandiangan dan Nainggolan, 2006c). Kultur sel diinkubasi pada suhu kamar dan diagitasi pada kecepatan $120 \mathrm{rpm}$. Subkultur dilakukan selelah 14 hari dengan cara mengganti medium cair yang lama dengan medium cair yang baru dengan komposisi nutrisi yang sama dengan medium sebelumnya.

\section{Perlakuan Triptofan dalam Erlenmeyer}

Sel hasil kultur dipisahkan dari media, kemudian media sisa pada sel dikeringkan menggunakan kertas hisap dalam pretridish steril, kemudian ditimbang. Wadah kultur yang digunakan adalah labu Erlenmeyer $100 \mathrm{~mL}$. Setiap Erlenmeyer berisi $25 \mathrm{~mL}$ medium cair MS dengan kombinasi zpt yang sama dengan medium produksi kalus tapi tanpa agar. Subkultur dalam Erlenmeyer dengan perlakuan triptofan $0,50,100,150,200,250 \mathrm{mg} / \mathrm{L}$ dilakukan langsung pada saat subkultur kedua. Setiap perlakuan dibuat 4 ulangan. Berat inokulum yang digunakan dalam kultur dalam Erlenmeyer adalah $2 \mathrm{~g}$ sel. Sel ditimbang secara aseptik dalam Laminar airflow ketika sedang subkultur.

Pertumbuhan sel ditentukan dengan cara menimbang berat basah sel. Sel-sel agregat ditimbang dalam timbangan digital dengan ketelitian 4 desimal. Pengukuran berat dilakukan pada hari setiap panen atau pengambilan sampel yaitu hari ke 0 (sekitar 6-8 jam selelah perlakuan), ke-4, 7, 10, 14, 17, dan 21.

\section{Panen dan Pengambilan Sampel}

Sel yang dipanen diprioritaskan berumur 14 hari selelah subkultur dalam triptofan dan masing-masing sel perlakuan dalam Erlenmeyer diukur berat basahnya. Sel dikeringkan dalam freeze dryer untuk dipergunakan pada analisis metabolit sekunder seperti kandungan katarantinnya dan metabolit terkait lainnya dengan HPLC.

\section{Pengamatan Spesialisasi Sel melalui Pengamatan Bentuk Sel}

Pengamatan Spesialisasi sel melalui perubahan bentuk sel tunggal akibat perlakuan prekursor triptofan dilakukan dengan mengikuti metoda Kim et al. (1994). Pengamatan dilakukan dengan mengambil satu tetes medium kultur yang baru diaduk. Medium yang digunakan adalah medium yang belum dilakukan penyaringan atau pemisahan antara sel dengan medium. Tetesan medium diletakkan diatas objek glass, kemudian diamati di bawah mikroskop Nikon Halogen 100 W dengan perbesaran $10 \times 10$. Setiap lapang pandang di foto dengan camera digital Nikon DXM 1200F. Bentuk sel diamati dari hasil foto yaitu sel berbentuk silinder dan bulat. Fokus perhatian adalah sel yang panjang (silinder) pada setiap lapang pandang. Persentase sel panjang dihitung dengan membandingkan jumlah sel yang silinder atau memanjang dengan total sel. Sel dikatakan 
silinder atau memanjang apabila mempunyai ratio $\geq$ 1,5 (Kim et al., 1994). Ratio sel ditentukan dengan membandingkan antara panjang $(\mu \mathrm{m})$ dengan lebar sel $(\mu \mathrm{m})$. Persentase sel silinder atau panjang diperoleh dengan rumus berikut:

$\frac{\text { Jumlah sel berbentuk silinder atau ratio } \geq 1,5}{\text { Jumlah total sel per lapang padang }} \times 100 \%$

\section{Analisis Data}

Data hasil penelitian akan disajikan dalam bentuk persentase, tabel, grafik atau kurva sesuai dengan jenis data yang diperoleh dalam percobaan. Uji statistik untuk mengetahui kandungan katarantin pada sel dan medium dilakukan dengan analisis varian (ANOVA) dalam rancangan acak lengkap (RAL) pada tingkat kepercayaan 95\%. Jika terlihat adanya perbedaan yang nyata, maka dilanjutkan dengan post hoc test DMRT (Duncan's multiple range test) pada tingkat kepercayaan $95 \%$.

\section{HASIL DAN PEMBAHASAN}

Pengaruh perlakuan triptofan terhadap pertumbuhan sel secara kualitatif atau pengamatan visual menunjukkan bahwa perlakuan triptofan tidak selalu meningkatkan pertumbuhan sel dengan meningkatnya konsentrasi triptofan. Pengamatan menunjukkan bahwa hari kultur juga menentukan perbedaan pengaruh pada pertumbuhan sel. Sel pada T2, T3 dan T4 nampak lebih banyak dan lebih tahan terhadap kontaminan. Kultur T2 - T4 jarang sekali mengalami kontaminasi dari 4 kali pengulangan. Hal itu kemungkinan ada kaitannya dengan perlakuan triptofan. Pada konsentrasi perlakuan tersebut pertumbuhan sel nampak optimum pada hari ke-14 sampai 21 (Gambar 1). Pengamatan dilakukan dalam berbagai ke-0, 4, 7, 10, 14, 18, dan 21.

Kultur sel hasil kultur dalam perlakuan berbagai variasi triptofan dapat dilihat pada Tabel 1. Pada tabel tersebut hanya ditampilkan contoh pengamatan pada hari ke-14 selelah kultur dalam prekursor triptofan. Dalam tabel tersebut ditunjukkan bahwa pertumbuhan sel yang baik secara visual dapat juga ditunjukkan dari perubahan warna sel $C$. roseus. Sel yang tumbuh baik cenderung berwama kekuningan agak keruh sedangkan yang kurang dapat tumbuh dengan baik berwarna kuning sampai kecoklatan.

Pengamatan secara mikroskopis terhadap sel-sel yang terjadi dalam kultur sel juga menunjukkan pengaruh yang signifikan perlakuan triptofan. Pengaruh yang ditimbulkan terutama diamati pada spesialisasi sel melalui pengamatan bentuk sel tersebut pada mikroskop Nikon Halogen 100W pada perbesaran 10x10 yang didokumentasikan dengan kamera digital Nikon DXM 1200F.

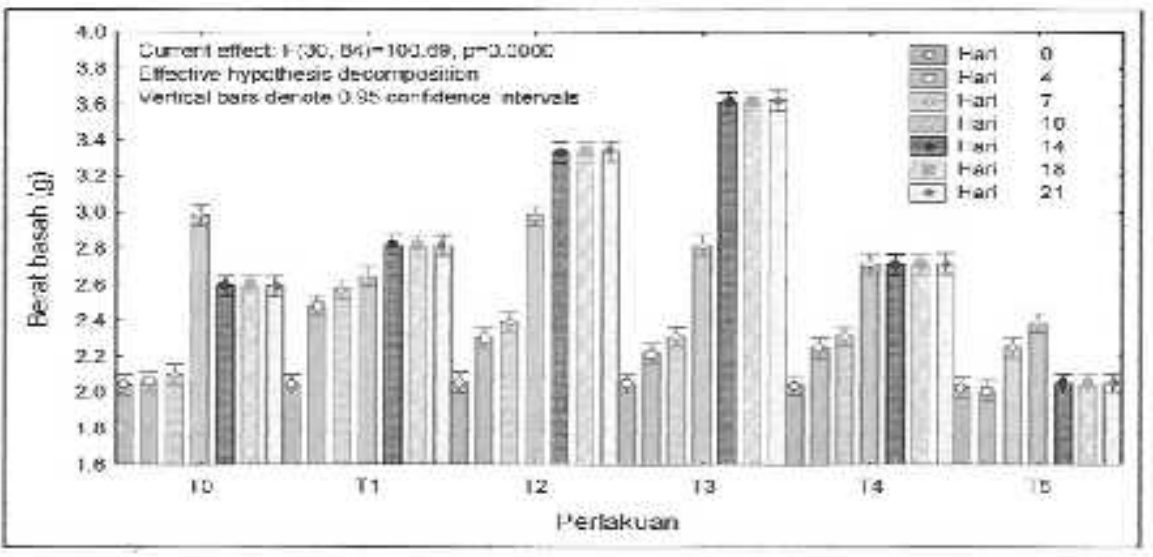

Gambar 1. Pertumbuhan sel $C$. roseus yang diukur melalui berat basah (g) pada Erlenmeyer dengan perlakuan triptofan pada hari kultur yang bebeda-beda dari 0, 4, 7, 10, 14, 18 dan 21 hari pengukuran pada masing-masing perlakuan triptofan (mg/L) 0 (T0); 50 (T1); 100 (T2); 150 (T3); 200 (T4) dan 250 (T5).

(Figure 1. The growth $C$. roseus cell aggregate that measured by wet weight $(g)$ in Erlenmeyer with tryptophan treatment on the dent culture day from 0, 4, 7, 10, 14, 18 dan 21 th day of measurement at each treatment of tryptophan (mg/L) 0 (T0); 50 (T1); 100 (T2); 150 (T3); 200 (T4) dan 250 (T5)) 
Tabel 1. Pengamatan kualitatif dari kultur sel C.roseus (C. roseus) yang diberi perlakuan triptofan ( $\mathrm{mg} / \mathrm{L})$ kontrol (T0); 50 (TI); 100 (T2); 150 (T3); 200 (T4) dan 250 (T5) setelah 14 hari kultur

(Table 1. Qualitative observations of cultured cell aggregates vinca (C. roseus) treated with tryptophan ( $\mathrm{mg} / \mathrm{L}$ ) control (T0), 50 (TI), 100 (T2), 150 (T3), 200 (T4) and 250 (T5) after 14 days of culture)

\begin{tabular}{|c|c|c|c|c|c|c|}
\hline $\begin{array}{c}\text { Variabel } \\
\text { pengamatan }\end{array}$ & T0 & $\mathrm{T} 1$ & T2 & T3 & $\mathrm{T} 4$ & T5 \\
\hline Bentuk sel & $\begin{array}{c}\text { sel bulat kecil } \\
\text { ada } \\
\text { memanjang }\end{array}$ & $\begin{array}{l}\text { sel bulat, ada } \\
\text { memanjang }\end{array}$ & $\begin{array}{c}\text { sel bulat, dan } \\
\text { memanjang }\end{array}$ & $\begin{array}{c}\text { sel bulat, clan } \\
\text { memanjang }\end{array}$ & $\begin{array}{l}\text { sel butat, dan } \\
\text { memanjang }\end{array}$ & $\begin{array}{l}\text { sel bulat, } \\
\text { ada } \\
\text { memanjang }\end{array}$ \\
\hline $\begin{array}{c}\text { Ratio } \\
\text { (panjang/lebar) }\end{array}$ & $115-5-47 \%$ & $1,5-7=56 \%$ & $1,5-6=65 \%$ & $1,5-12=75 \%$ & $1,5-7-60 \%$ & $1,5-7=48 \%$ \\
\hline $\begin{array}{l}\text { Penampakan } \\
\text { kultur }\end{array}$ & $\begin{array}{l}\text { agak kreruh } \\
\text { kuning muda }\end{array}$ & $\begin{array}{l}\text { agak kreruh } \\
\text { kuning muda }\end{array}$ & $\begin{array}{l}\text { agak kreruh } \\
\text { kuning muda }\end{array}$ & $\begin{array}{l}\text { agak kreruh } \\
\text { kuning muda }\end{array}$ & $\begin{array}{l}\text { agak bening } \\
\text { kekuningan }\end{array}$ & $\begin{array}{l}\text { agak coklat } \\
\text { kekuningan }\end{array}$ \\
\hline $\begin{array}{c}\text { Persentasi sel } \\
\text { panjang }(\%)\end{array}$ & 47 & 56 & 65 & 75 & 60 & 48 \\
\hline Suspensi & $\begin{array}{c}\text { agak banyak } \\
++\end{array}$ & $\begin{array}{c}\text { agak banyak } \\
++\end{array}$ & $\begin{array}{l}\text { sedikit } \\
+\end{array}$ & $\begin{array}{c}\text { sangat banyak } \\
++++\end{array}$ & $\begin{array}{c}\text { banyak } \\
+++\end{array}$ & $\begin{array}{c}\text { banyak } \\
+++\end{array}$ \\
\hline $\begin{array}{l}\text { Berat sel } \\
\text { (g) }\end{array}$ & 2,545 & 2,775 & 3,275 & 3,555 & 2,665 & 2,015 \\
\hline Berat awal (g) & 2 & 2 & 2 & 2 & 2 & 2 \\
\hline Kenaikan BB & 0,545 & 0,775 & 1,275 & 1,555 & 0,665 & 0,015 \\
\hline $\begin{array}{c}\text { Persentasi } \\
\text { kenaikan BB (\%) }\end{array}$ & 2725 & 38,75 & $6-3,75$ & 77,75 & 33,25 & 0,75 \\
\hline Warna Sel & $\begin{array}{l}\text { Putih + } \\
\text { Kehitaman }\end{array}$ & Putih & Coklat & putih abu-abu & $\begin{array}{c}\text { coklat } \\
\text { kekuningan }\end{array}$ & $\begin{array}{c}\text { coklat } \\
\text { kekuningan }\end{array}$ \\
\hline
\end{tabular}

Hasilnya dapat dilihat pada Gambar 2 setelah dikultur 10 hari dan Gambar 3 setelah dikultur 14 hari. Bentuk sel pada kontrol relatif kecil ratio antara panjang dengan lebarnya atau selselnya relatif berbentuk bulat dan sel yang memanjangnya sedikit. Sedangkan sel pada perlakuan triptofan meningkat jumlah sel yang panjang dan ratio selnya juga bertambah dari $\mathrm{T} 1$ sampai pada T4. Sel yang diberi perlakuan triptofan 150 sampai $200 \mathrm{mg} / \mathrm{L}$ lebih besar persentasi sel yang panjang (mengalami spesialisasi), juga ratio sel juga sangat besar. Ratio tersebut dapat mencapai 8-12 (Tabel 1, Gambar 2 dan Gambar 3). Bentuk sel yang panjang pada T3 dan T4 kemungkinan ada kaitannya dengan aktivitas TDC (Pandiangan et al., 2011), kandungan IAA (Pandiangan, 2010) dan kandungan katarantin
(Pandiangan et al., 2006). Hubungan ini akan dijelaskan pada topik pembahasan berikutnya.

Setelah diuji secara satistik bahwa hasil perlakuan prekursor triptofan dalam Erlenmeyer terhadap spesialisasi sel melalui pengamatan bentuk sel sangat berbeda nyata. Bentuk sel kontrol relatif mempunyai ratio antara panjang dan lebar yang lebih besar dari 1,5 maksimal $47 \%$ dan ratio paling tinggi sekitar 5. Sedangkan perlakuan triptofan mempunyai ratio selnya sangat besar bahkan mencapai 12, meskipun tidak selalu meningkat dengan meningkatnya konsentrasi perlakuan triptofan. Perlakuan yang mempunyai ratio paling tinggi adalah pada perlakuan antara 150 dan $200 \mathrm{mg} / \mathrm{L}$ triptofan. 


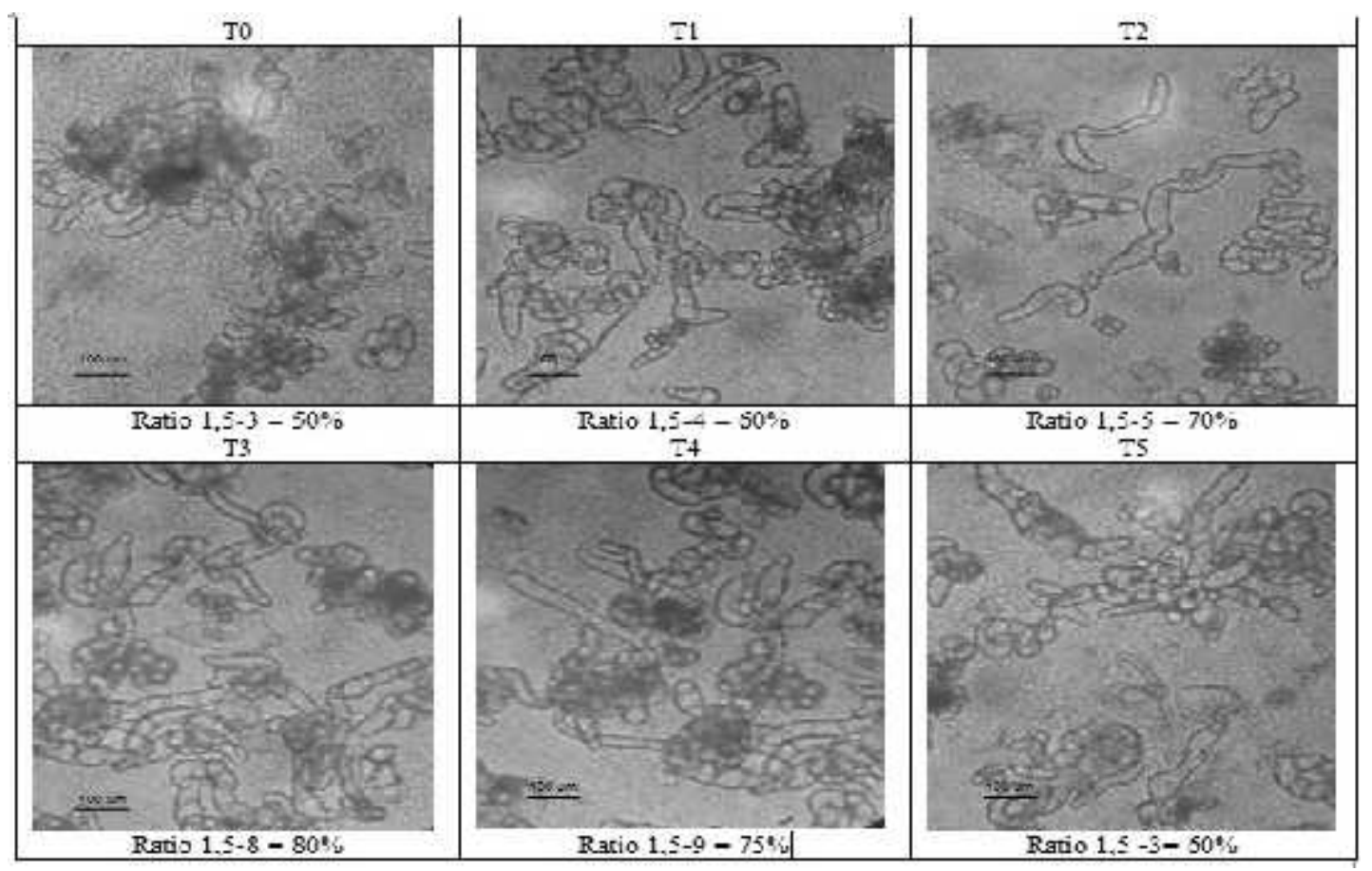

Gambar 2. Spesialisasi sel melalui pengamatan bentuk sel Catharanthus roseus hari ke 10 selelah kultur dalam media perlakuan triptofan. T0 (0 mg/L), T1 (50 mg/L), T2 (100 mg/L), T3 (150 mg/L), T4 (200 mg/L) dan T5 (250 mg/L)

(Figure 2. The cell specialization throuh morphological observation C. roseus cell that measured day 10th after treated with tryptophan. T0 (0 mg/L), T1 (50 mg/L), T2 (100 mg/L), T3 (150 mg/L), T4 (200 mg/L) dan T5 (250 mg/L)

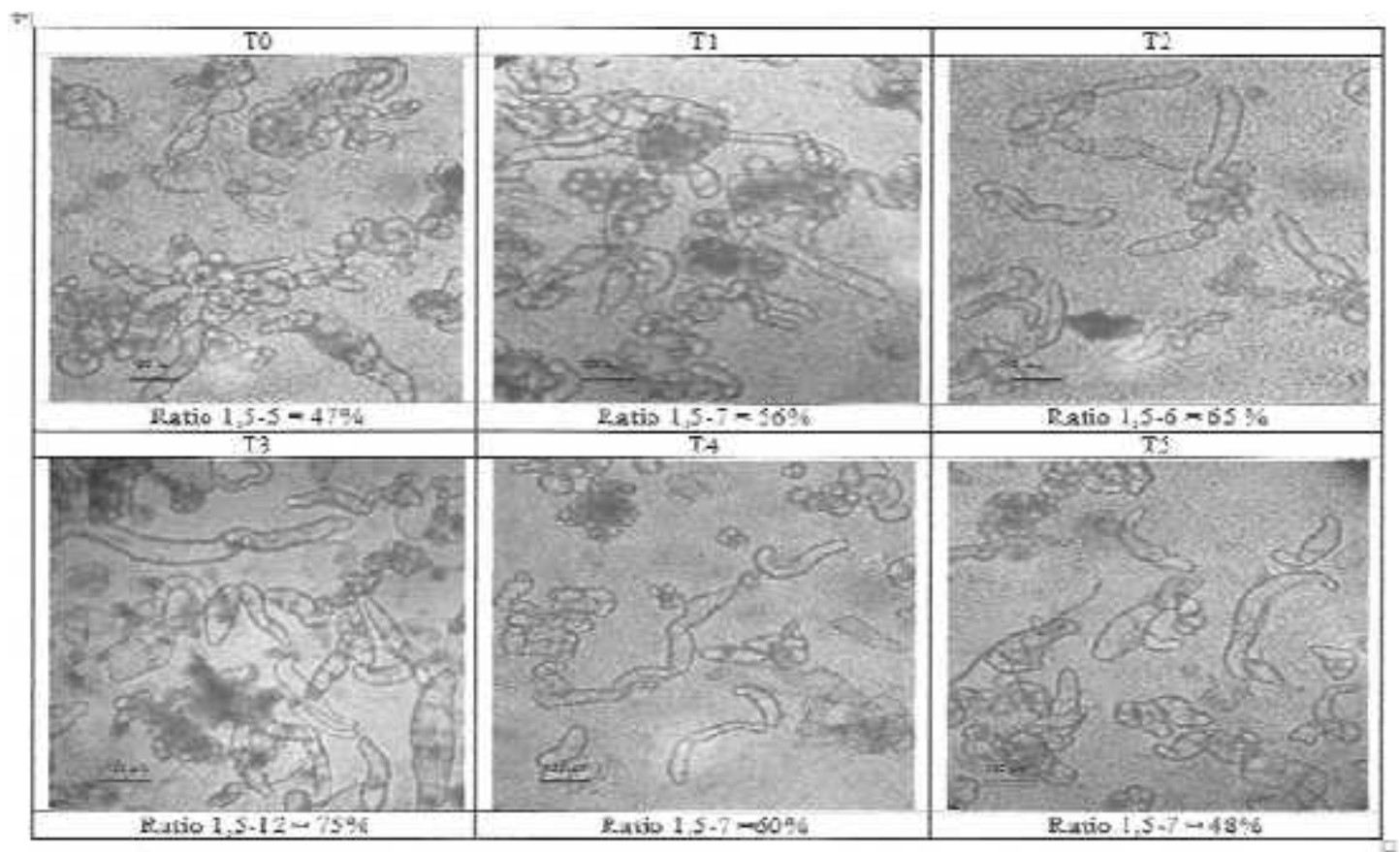

Gambar 3. Spesialisasi sel melalui pengamatan bentuk sel Catharanthus roseus hari ke 14 selelah kultur dalam media perlakuan triptofan. T0 (0 mg/L), T1 (50 mg/L), T2 (100 mg/L), T3 (150 mg/L), T4 (200 mg/L) dan T5 (250 mg/L)

(Figure 3. The cell specialization throuh morphological observation C. roseus cell that measured day $14^{\prime} \mathrm{h}$ after treated with tryptophan. T0 (0 mg/L), T1(50 mg/L), T2 (100 mg/L), T3 (150 mg/L), T4 (200 mg/L) dan T5 (250 $\mathrm{mg} / \mathrm{L})$ 
Persentase sel yang silindris atau bentuk memanjang semakin meningkat setelah diberikan perlakuan triptofan sudah dimulai dari hari ke-7 dan 10 setelah perlakuan (Gambar 2). Ukuran sel dan bentuk memanjang semakin meningkat rationya sampai pada hari ke-14 dan 21 setelah perlakuan triptofan T3 atau $150 \mathrm{mg} / \mathrm{L}$ (Gambar 3). Proses semakin memanjangnya sel-sel tersebut diduga merupakan suatu proses spesialisasi sel penghasil metabolit sekunder, salah satunya adalah katarantin. Menurut Moreno-Valenzuela (1998), bahwa sel yang mengalami spesialisasi dan difrensiasi mengandung metabolit sekunder yang lebih tinggi daripada yang tidak mengalami spesialisasi. Demikian juga Kim et al. (1994) melaporkan bahwa sel yang benbentuk memanjang (ratio selnya tinggi) mengandung alkaloid yang lebih tinggi daripada yang berbentuk bulat (ratio selnya kecil).

Hari atau lamanya kultur juga menentukan terhadap perubahan ratio sel dan besar sel. Pada hari ke-14 sampai ke-21 merupakan hari kultur yang paling maksimal ratio selnya yaitu sekitar 10 12. Pada hari itu juga sel kelihatan membesar, diduga akan mengalami pembelahan sel selanjutnya. Pada hari 28 sudah lebih kecil diduga karena sudah mengalami pembelahan sel sebelum

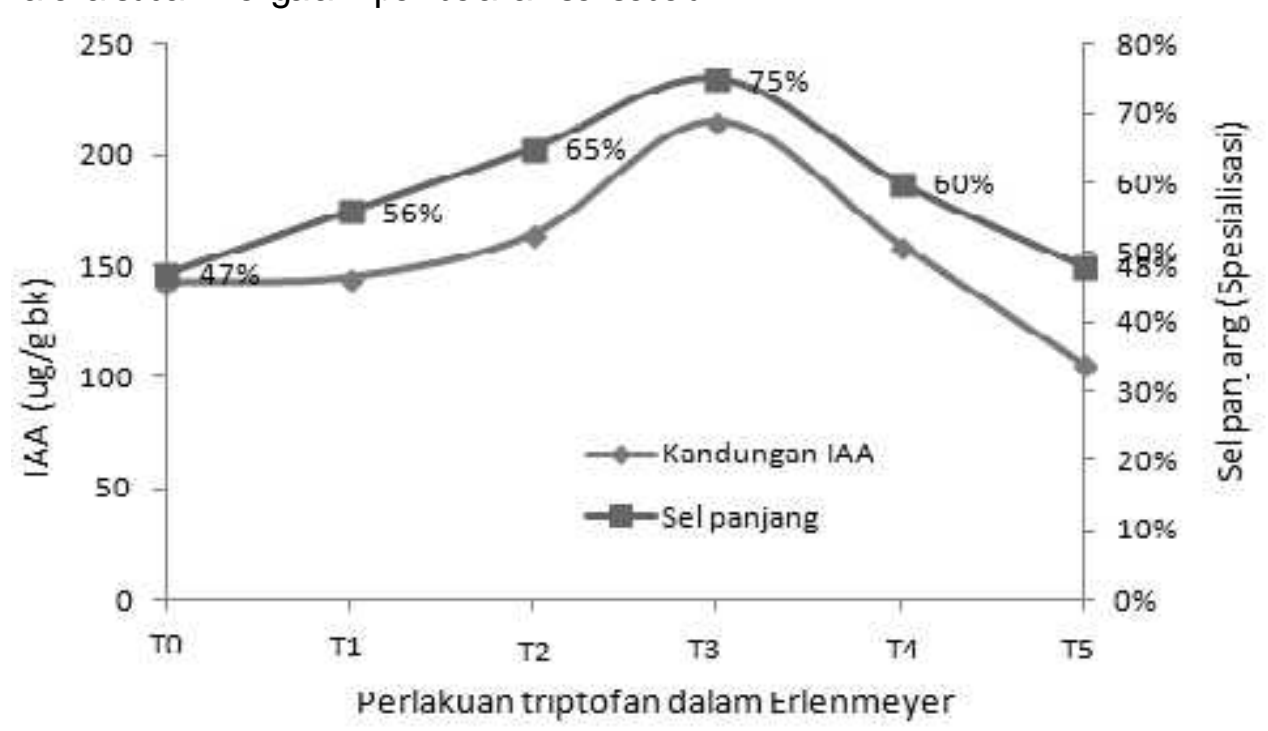

Gambar 4. Pola kandungan IAA ( $\mu \mathrm{g} / \mathrm{g}$ bk) dengan sel panjang (\%) yang mengalami spesialisasi pada hari ke-28 (masih perlu pembuktian pada penelitian selanjutnya).

Peningkatan persentasi sel yang memanjang juga berkaitan erat dengan peningkatan kandungan IAA yang sudah dilakukan sebelumnya (Pandiangan, 2010). Penambahan triptofan dengan variasi konsentrasi yang sama dicobakan kembali dan diperoleh hasil seperti pada Gambar 3. Setelah dicari hubungannya atau korelasinya maka diperoleh korelasi positif sebesar 0,80 . Korelasi ini cukup besar untuk mendorong peningkatan pemanjangan sel atau spesialisasi sel. Hal ini dapat terjadi oleh karena IAA merupakan salah satu hormon pertumbuhan yang berfungsi pada pemanjangan sel (Salisbury dan Ross, 1992).

Kandungan IAA mengalami peningkatan sampai pada T4 dari kontrolnya. Kandungan IAA tertinggi terdapat pada T3 setelah 14 hari kultur dengan perlakuan triptofan yaitu sebesar $214,79 \pm 0,90 \quad(\mu \mathrm{g} / \mathrm{g} \quad$ bk $)$ dan peningkatannya mencapai 50,60\% terjadi pada T3 (Pandiangan, 2010). Tetapi berbeda dengan T5, justru 25,77\% (Pandiangan, 2010). Penurunan ini mungkin disebabkan $\mathrm{pH}$ yang semakin tinggi pada perlakuan tersebut (Gambar 5). mengalami penurunan kandungan IAA sebesar

\footnotetext{
beberapa konsentrasi triptofan triptofan (mg/L) 0 (T0), 50 (T1), 100 (T2), 150 (T3), 200 (T4), 250 (T5), pada sel $C$. roseus setelah 14 hari kultur dalam Erlenmeyer.

(Figure 4. Pattern IAA content $(\mu \mathrm{g} / \mathrm{g} \mathrm{dw})$ and cell length (\%) who have specialized in the treatment of multiple concentrations of tryptophan (mg/L) 0 (T0), 50 (T1), 100 (T2), 150 (T3), 200 (T4), 250 (T5) at the $C$. roseus cell culture after 14 days of culture in the Erlenmeyer)
} 


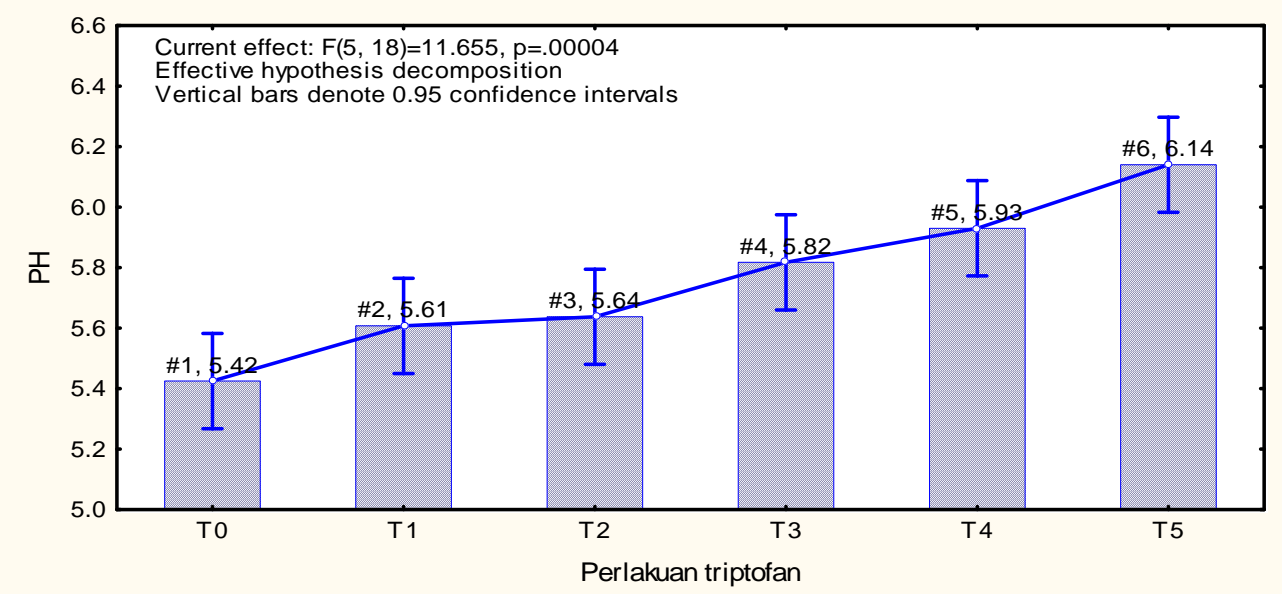

Gambar 5. Peningkatan $\mathrm{pH}$ dengan meningkatnya perlakuan triptofan pada beberapa konsentrasi triptofan triptofan (mg/L) 0 (T0), 50 (T1), 100 (T2), 150 (T3), 200 (T4), 250 (T5), pada sel C. roseus setelah 14 hari kultur dalam Erlenmeyer.

(Figure 5. The increase of $\mathrm{pH}$ with increasing tryptophan concentrations in some (mg/L) 0 (T0), 50 (T1), 100 (T2), 150 (T3), 200 (T4), 250 (T5), the C. roseus cell after 14 days of culture in the Erlenmeyer)

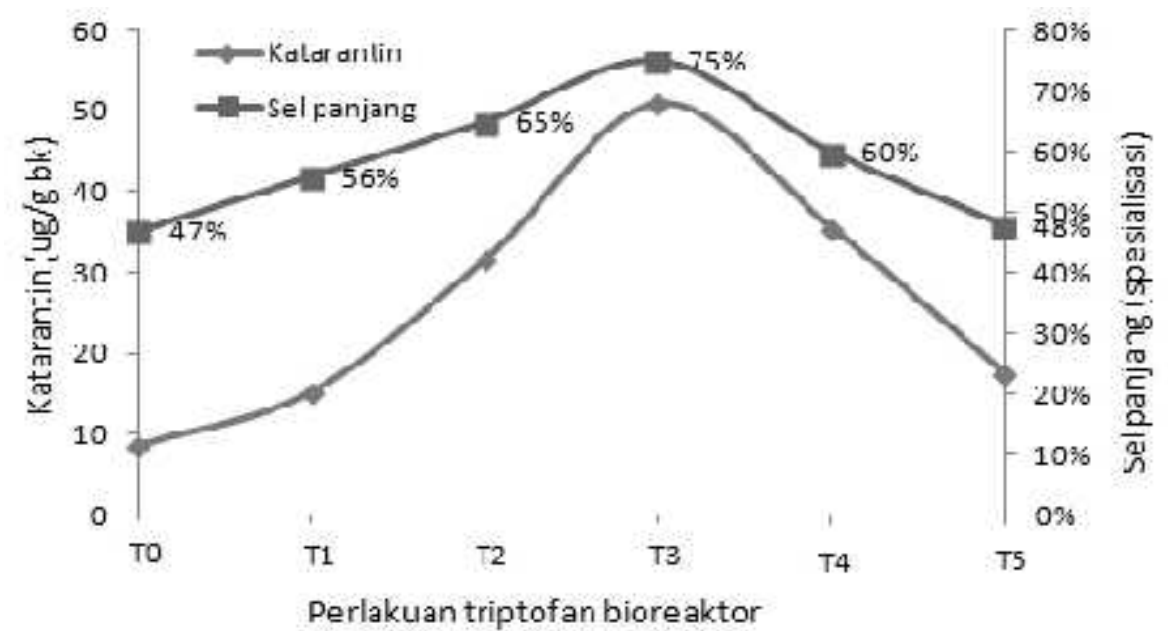

Gambar 6 . Pola kandungan katarantin $(\mu \mathrm{g} / \mathrm{g}$ bk) dan sel panjang (\%) yang terspesialisasi dari sel C.roseus yang diberi prekursor triptofan, 50 (T1), 100 (T2), 150(T3), 200 (T4) dan 250 (T5) mg/L dan kontrol (T0) dalam Erlenmeyer pada hari ke- 14 selelah kultur.

(Figure 6. The pattern of catharanthine content $(\mu \mathrm{g} / \mathrm{g} \mathrm{dw})$ and specialized cell (long cells) of C.roseus cell in Erlenmeyer with tryptophan treatment (mg/L) 0 (T0); 50 (T1); 100 (T2); 150 (T3); 200 (T4) dan 250 (T5) at $14^{\text {th }}$ day after treatment)

Berdasarkan hasil uji korelasi antara perlakuan triptofan dan $\mathrm{pH}$ bahwa perlakuan triptofan meningkatkan $\mathrm{pH}$ pada media setelah steril dan setelah kultur 14 hari. Kultur sel membutuhkan $\mathrm{pH}$ optimum (Lehninger, 1990) agar dapat menginduksi aktivitas Enzim sintesis IAA. Kultur sampai hari ke-21 pH mengalami peningkatan. Pada Gambar 5 ditunjukkan bahwa pada hari ke-14 setelah kultur bahwa $\mathrm{pH}$ mencapai sekitar 6 pada T3.
Berdasarkan pada hasil analisis ANOVA, perlakuan triptofan dari 50, 100, 150, 200 dan 250 $\mathrm{mg} / \mathrm{L}$ mempunyai pengaruh yang sangat nyata terhadap kandungan katarantin dalam sel. Kandungan katarantin maksimum terdapat pada perlakuan T3 yaitu sebesar 50,96 $\mu \mathrm{g} / \mathrm{g}$ bk (Gambar 6). Hasil uji lanjut DMRT menunjukkan bahwa perlakuan triptofan mempunyai pengaruh yang signifikan terhadap kandungan katarantin dalam sel pada hari ke-14. Peningkatan kandungan katarantin 
tersebut juga sejalan atau berhubungan dengan peningkatan sel yang memanjang atau yang mengalami spesialisasi menjadi sel yang diduga merupakan sel latisifer. Pola kandungan katarantin dan penanjangan sel tersebut ditunjukkan seperti pada Gambar 6. Pada gambar tersebut nampak pola yang sama. Kandungan katarantin paling tinggi juga menunjukkan sel yang terspesialisasi lebih besar. Hubungan antara sel yang mengalami spesialisasi dan kandungan katarantin juga mempunyai korelasi positif sebesar sebesar 0,83 atau $83 \%$ saling mendukung. Demikian juga halnya hubungan pemanjangan sel atau spesialisasi sel dengan kandungan IAA dalam sel kultur sel $C$. roseus menunjukkan hubungan atau korelasi positif sebesar 0,80 atau $80 \%$ saling menunjang serta polanya mirip.

\section{KESIMPULAN}

Bentuk sel pada dasarnya sama untuk setiap perlakuan. Perbedaan yang terlihat nyata adalah adanya sel-sel panjang lebih banyak pada perlakukan triptofan. Perlakuan yang paling panjang rationya adalah pada perlakuan $150 \mathrm{mg} / \mathrm{L}$ triptofan pada hari ke-14 kultur. Hubungan perubahan bentuk sel yang lebih banyak panjang (mengalami spesialisasi) ada hubungannya dengan kandungan IAA dan katarantin yang meningkat selelah perlakuan triptofan. Kandungan IAA paling tinggi yaitu sebesar $214,79 \pm 0,90 \mu \mathrm{g} / \mathrm{g}$ bk juga pada hari ke 14 selelah diberi perlakuan triptofan $150 \mathrm{mg} / \mathrm{L}$ dengan persentasi sel panjang atau sel mengalami spesialisasi $75 \%$. Hubungan antara spesialisasi sel dengan kandungan IAA menunjukkan hubungan yang positif sebesar 0,80 atau $80 \%$ saling menunjang.

\section{UCAPAN TERIMA KASIH}

Penelitian ini didanai oleh Daftar Isian Pelaksanaan Anggaran (DIPA) Nomor 0748/02304.2.01/27/2012 Tanggal 9 Desember 2011 Tahun Anggaran 2012 Satuan Kerja Universitas Sam Ratulangi Kementerian Pendidikan dan Kebudayaan Republik Indonesia. Untuk itu diucapkan banyak terimakasih atas bantuan dana dari pemerintah.

\section{DAFTAR PUSTAKA}

Alexandrova, R., I. Alexandrova, M.Velcheva, and T. Varadinova. 2000. Phytoproduct and Cancer. Experimental Pathology and Parasitology. Bulgarian Academy of Sciences.

Darsini, N.N. 2001. Perkembangan Latisfer pada Kultur Kalus Catharanthus roseus (L.) G. Don

De Padua, L.S., N. Bunyapraphatsara and R.H.M.J. Lemmens (Editors). 1999. Plant Resources of South East Asia no. 12(1). Medicinal and Poisonous plants 1. PROSEA Foundation, Bogor, Indonesia. p. 185-190

Dutta A., J. Batra., S. Pandey-Rai, D. Singh, S. Kumar, and J. Sen. 2005. Expression of terpenoid indol alkaloid biosynthetic pathway genes corresponds to accumulation of related alkaloid in Catharanthus roseus (L.) G. Don. Planta. Spinger-Verlag. New Delhi. 220:376-383.

Girod, P.A. and J.P. Zryd. 1991. Secundary metabolism in culture red beet (beta vulgaris $\mathrm{L}$.) cells: differentional regulation of betaxanthin and betacyanin biosynthesis. Plant Cell Tissue Organ Culture 25: 1-12.

Kim, S.W., K. H. Jung, S. S. Kwak, and J. R. Liu. 1994. Relationship between cell morphology and indole alkaloid production in suspension cultures of Catharanthus roseus. Plant Cell Report 14: 23-26.

Lehninger, A.L. 1990. Principles of Biochemistry $4^{\text {th }}$ Edition. D.L. Nelson and M.M.. Cox (Eds). pp. 671-680, Worth Publisher, Inc.

Moreno-Valenzuela, O.A., R.M. Galaz-Avalos, Y. Minero-Garcia, and V. M. Loyola-Vargas. 1998. Effect of diffrentiation on the regulation of indole alkaloid production in Catharanthus roseus hairy roots. Plant Cell Reports. 18: 99-104. 
Pandiangan, D. 2010. Hubungan Kandungan IAA dengan Pertumbuhan yang Dihasilkan dari Kultur Agregat Sel Catharanthus roseus yang Diberi Perlakuan Triptofan dalam Erlenmeyer. Jurnal IImiah Sains 10(2) p. 229-234.

2011. Produksi Katarantin melalui Kultur Jaringan. Penerbit CV. Lubuk Agung Bandung. -- dan N. Nainggolan. 2006a, Produksi Alkaloid dari kalus tapak dara, Jurnal IImiah Sains, 6, 48-54.

2006b. Peningkatan produksi katarantin pada kultur kalus C. roseus yang diberi NAA. Jurnal Hayati 13:3 p.90-94

2006c. Respons pertumbuhan dan kandungan katarantin kalus $C$. roseus yang diberi asam 2,4Diklorofenoksi aselat. Eugenia 12:3, p. 184-195.

D. Rompas, H. Aritonang, R. Esyanti, dan E. Marwani. 2006. Pengaruh triptofan terhadap pertumbuhan dan kandungan katarantin pada kultur kalus $C$. roseus. Jurnal Matematika dan Sains 11:4,111-118.

R.R. Esyanti, V. Usviany, and W. Wulansari. 2008. Production of catharanthine in Catharanthus roseus aggregate cell cultures by feeding, elicitation and immobilization method. Proceedings International Conference on Mathematics and Natural Sciences (ICMNS) November, 2008, BandungIndonesia. p. 379-386.
Salisbury, F.B. and C.W. Ross. 1992. Plant Physiology, $4^{\text {th }}$ edition. Wadsworth Publishing. Co. Ch.15; Ch.17.

Sutarno, H. and Rudjiman. 2003. Plant Resources of South East Asia No 1. Medicinal and Poisonous Plants, Baclihuys Publisherds, Leiden.

Wilken, D., E.J.Gonzalez, A. Hohe, M. Jordan, R. G Kosky, G. S, Hirschmann and A. Gerth. 2005. Comparison Of Secondary Plant Metabolite Production In Cell Suspension, Callus Culture And Temporary Immersion System. In A. K. Hvoslef-Eide and W. Preil (Eds) Liquid Culture Systems For In Vitro Plant Propagation. pp.525-538. Springer Netherlands

Zhong, J. J. 2001. Biochemical Engineering of the Production of Plant-Specific Secondary Metabolites by Cell Suspension Cultures. Dalam: Advances in Biochemical Engineering. Springer-Verlag Berlin Heidelberg. Germany. 
